\section{Public Health Needs You!}

I came back from the recent Canadian Public Health Association annual conference in Edmonton both energized and depressed. Energized because the conference illustrated the dynamism and dedication of public health practitioners and researchers who in spite of substantial obstacles continue to advance the science and application of population health. Depressed because the meeting was an opportunity to reflect on the state of our field and it is not good. The Canadian public health system is facing its most serious challenges in over a decade.

The challenges we face today come not from external threats such as SARS and water contamination, as we experienced in the early 2000s, but from ourselves. Canadian society is becoming more unequal, more divided by social class, more individualistic, less interested in achieving health and social equality and less willing to invest in or even to value the collective good. National and provincial governments are reducing investments in the public health sector and civil society. Economic and other policies threaten the environment and the health and well-being of many Canadians, while our social safety net is showing definite signs of rupture. The apparent lack of concern of our elites for the less well-off in society is disconcerting and worrisome for the very fabric of our country. First Nations people, recent immigrants, refugees, ethnic and sexual minorities and other vulnerable populations deserve our earnest efforts towards their improved health and well-being, and not the neglect that they often seem to get.

The economic crisis of 2008 and the subsequent policy responses have failed to result in needed increases in funding for infrastructures and social programs to reduce inequalities and promote a more just society. We are fooling ourselves if we think that the economic crisis can be solved by decreased government spending, particularly in the social sector. To paraphrase Winston Churchill, economics is too important to be left to economists. The crisis is a crisis of values and it can only be solved through engagement of all sectors of society and through national discussion and debate about Canada's future. This is, in effect, a challenge to our democracy. Although it may seem distant from our day-to-day public health practice, the values and principles of public and population health are of critical importance to this debate. Now more than ever, public health needs a strong voice to advocate for social justice. Public health needs us all, will we respond?

Gilles Paradis

Scientific Editor

\section{La santé publique a besoin de vous!}

À mon retour de la récente conférence annuelle de l'Association canadienne de santé publique à Edmonton, j'étais à la fois énergisé et déprimé. Énergisé parce que la conférence a montré le dynamisme et le dévouement des praticiens et des chercheurs en santé publique qui, malgré des obstacles considérables, continuent à faire avancer et à appliquer la science de la santé des populations. Déprimé parce que cette rencontre nous a permis de faire des bilans - et que la situation n'est pas rose. Le système canadien de santé publique fait face aux pires difficultés en plus de 10 ans.

Les difficultés d'aujourd'hui ne sont pas des menaces extérieures comme le SRAS et la contamination de l'eau au début des années 2000 : elles viennent de nous. La société canadienne devient plus inégalitaire, plus divisée en classes sociales, plus individualiste, moins intéressée à atteindre la santé et l'égalité sociale et moins disposée à investir dans le bien collectif, ou même à lui accorder une valeur quelconque. Les gouvernements fédéral et provinciaux réduisent leurs investissements dans le secteur de la santé publique et la société civile. Les politiques économiques et autres menacent l'environnement, la santé et le bien-être de nombreux citoyens, et notre filet de sécurité sociale montre des signes de rupture évidents. L'indifférence apparente de nos élites envers les moins-nantis de la société est déconcertante et inquiétante pour le tissu même de notre pays. Les Premiers Peuples, les immigrants récents, les réfugiés, les minorités ethniques et sexuelles et autres populations vulnérables méritent nos efforts sincères pour améliorer leur santé et leur bienêtre, et non la négligence qui semble trop souvent leur lot.

La crise économique de 2008 et les politiques qui en ont découlé n'ont pas donné lieu à des augmentations, pourtant nécessaires, du financement des infrastructures et des programmes sociaux en vue de réduire les inégalités et de promouvoir une société plus juste. Nous nous trompons si nous pensons que la crise économique peut être résolue en réduisant les dépenses publiques, surtout dans le secteur social. Pour paraphraser Winston Churchill, l'économie est trop importante pour être laissée aux économistes. La crise est une crise de valeurs, et elle ne sera résolue qu'en mobilisant tous les secteurs de la société et en engageant un débat national sur l'avenir du Canada. Il s'agit en fait d'un défi lancé à notre démocratie. Même s'ils semblent éloignés de notre pratique quotidienne de la santé publique, les valeurs et les principes de la santé publique et des populations sont d'une importance névralgique dans ce débat. Maintenant plus que jamais, la santé publique a besoin d'un ardent défenseur de la justice sociale. La santé publique a besoin de nous tous - répondrons-nous à l'appel?

Le rédacteur scientifique, Gilles Paradis 